\title{
Cross-linked RNA Immunoprecipitation
}

Miriam Vogt and Verdon Taylor

Department of Biomedicine, University of Basel, Basel, Switzerland

*For correspondence: verdon.taylor@unibas.ch

[Abstract] This method is for the immunoprecipitation of Flag-Tagged RNA binding proteins from mammalian cell lines and isolation of the bound RNAs for analysis by quantitative real-time PCR. The RNA binding protein of interest should be tagged with the M2 Flag-tag and expressed in the mammalian cell line of interest (Knuckles et al., 2012). However, specific antibodies for the protein of interest can be used in conjunction with Sepharose G-beads.

\section{Materials and Reagents}

1. Anti-Flag M2 Affinity gel (Sigma Aldrich, catalog number: A2220)

2. RNase inhibitor (Life Technologies, Invitrogen ${ }^{\mathrm{TM}}$, catalog number: N8080119 or Bioline, catalog number: BIO-65028)

3. Complete Protease Inhibitor Cocktail Tablets (F. Hoffmann-La Roche, catalog number: 05892970 001)

4. RnaseZap (Life Technologies, Ambion ${ }^{\circledR}$, catalog number: AM9780)

5. Trizol reagent (Life Technologies, Invitrogen ${ }^{\mathrm{TM}}$, catalog number: 15596-026)

6. General chemicals (Sigma Aldrich)

7. DNase I recombinant, RNase-free inc. buffer (F. Hoffmann-La Roche, catalog number: 04716728001)

8. BioScript $^{\mathrm{TM}}$ (Bioline, catalog number: BIO-27036)

9. Formaldehyde

10. Fetal calf serum

11. Glycine

12. SDS

13. HEPES

14. TritonX-100

15. EDTA

16. DTT

17. $\mathrm{NaCl}$

18. IP lysis buffer (see Recipes)

19. RIP buffer (see Recipes) 


\section{Equipment}

1. Sonicator (the model is not critical but preferably a devise with a probe $\leq 5 \mathrm{~mm}$ in diameter)

2. Tube Rotator

3. Shaker

4. Centrifuge

5. PCR machine

6. Heating block

7. $15 \mathrm{ml}$ conical tubes

\section{Procedure}

A. Preparation of beads and cells

1. Blocking of the beads:

Wash $40 \mu \mathrm{l}$ Anti-Flag M2 Affinity Gel twice with $900 \mu$ of pure $\mathrm{H}_{2} \mathrm{O}$ (cold); add $400 \mu \mathrm{l}$ IP lysis buffer $+1 \% \mathrm{BSA}$; incubate at $4{ }^{\circ} \mathrm{C}$ (on a rotating wheel) overnight.

Alternatively use $30 \mu \mathrm{l}$ SepharoseG-Beads + specific antibody. The amount of antibody and beads to be used in the precoupling will need to be determined in preliminary experiments. Typically using $10 \mu \mathrm{g}$ of $\mathrm{Ig}$ for coupling is a reasonable starting point.

2. Use $2 \times 10 \mathrm{~cm}^{2}$ tissue culture plate per condition (this might vary depending on the cell type and the level of expression of the protein of interest). Do not process more than 10 plates at a time.

3. Transfect cells and incubate them for $48 \mathrm{~h}$ to express the tagged protein.

B. Harvesting the cells

4. Remove medium, wash the cells once with phosphate buffered saline and add $1 \mathrm{ml}$ $0.25 \%$ Trypsin (pre-heated to $37^{\circ} \mathrm{C}$ ). Incubate at $37^{\circ} \mathrm{C}$ until the cells start to detach.

5. Add $5 \mathrm{ml}$ DMEM including $10 \%$ fetal calf serum (pre-warmed to $37^{\circ} \mathrm{C}$ ) to inhibit the trypsin.

6. Remove the cells from the plate by pipetting.

7. Transfer the cells to a $15 \mathrm{ml}$ conical tube and incubate on ice for $5 \mathrm{~min}$.

8. Harvest cells $2 \mathrm{~min}$ at $100 \times \mathrm{g}$ at room temperature, decant the supernatant and resuspend the cell pellet in $5 \mathrm{ml}$ ice-cold phosphate buffered saline. Keep a $250 \mu \mathrm{l}$ aliquot for Western blot analysis to be used as a transfection control.

9. Add $143 \mu \mathrm{l} 37 \%$ formaldehyde (over a period of approximately $10 \mathrm{sec}$, treat all of the samples in the same way). 
10. Place the $15 \mathrm{ml}$ conical tubes on a rocking plate and shake for $10 \mathrm{~min}$ at room temperature.

11. Add $685 \mu \mathrm{l} 2 \mathrm{M}$ glycine (over a period of approximately $10 \mathrm{sec}$, treat all of the samples in the same way) to block the formaldehyde.

12. Place the $15 \mathrm{ml}$ conical tubes on a rocking plate and shake for $5 \mathrm{~min}$ at room temperature.

13. Harvest cells by centrifugation for 2 min at $100 \times g$ at room temperature.

14. Decant the supernatant and transfer the cell pellet to ice.

15. Wash the cells twice with $5 \mathrm{ml}$ ice-cold phosphate buffered saline and harvest the cells 2 $\min$ at $100 \times g$ at $4{ }^{\circ} \mathrm{C}$.

16. Remove the supernatant from the cells after the last wash and add $1 \mathrm{ml}$ of IP lysis buffer $+20 \mu \mathrm{l} 0.1 \mathrm{M}$ phenylmethylsulfonyl fluoride $+20 \mu \mathrm{l}$ complete protease inhibitor $(50 \mathrm{x})+5$ $\mu \mathrm{l}$ RNase inhibitor (40 $\mathrm{U} / \mathrm{ul}$ ) to each sample.

17. Sonicate the cells, keeping them on ice at all times, 10x (10 sec on, $10 \mathrm{sec}$ off, Amplitude $15 \mu \mathrm{m})$ until the lysate is clear. Clean probe sonicator with RNaseZap between the samples to avoid contamination with RNases.

18. Transfer the cells to a $1.5 \mathrm{ml}$ snap-cap tube and keep on ice.

19. Centrifuge the lysates for $3 \mathrm{~min}$ at $14,000 \times \mathrm{g}$ at room temperature and keep $50 \mu \mathrm{l}$ of the supernatant as an INPUT control (used to standardize the GPCR analysis).

C. Immunoprecipitation

20. Add the rest of the lysate to the blocked beads and incubate overnight at $4{ }^{\circ} \mathrm{C}$ on a rotating wheel.

21. Wash the beads 5 times with $900 \mu \mathrm{l}$ of IP lysis buffer collecting the beads by centrifugation for $1 \mathrm{~min}$ at $400 \times \mathrm{g}$ at room temperature.

22. Remove all of the supernatant after the last wash and add $100 \mu \mathrm{l}$ of RIP buffer $+1 \mu \mathrm{l}$ RNase inhibitor.

Add $50 \mu \mathrm{l}$ of RIP buffer to the INPUT control (step 18).

23. Incubate the samples and INPUT controls for $1 \mathrm{~h}$ at $70^{\circ} \mathrm{C}$ to reverse the cross-link.

24. Centrifuge for $1 \mathrm{~min}$ at $400 \times \mathrm{g}$ at room temperature to sediment the beads and collect $100 \mu$ of supernatant.

25. Extract the RNA with Trizol reagent (proceed according to the manufacturer'sinstruction (Invitrogen)). Optional: Add $1 \mu \mathrm{l}$ of Glycogen blue before precipitation of the RNA with Isopropanol to make the pellet visible. Precipitation can also be performed at $-20^{\circ} \mathrm{C}$ for 1 $h$ to increase the amount of precipitated RNA.

26. DNAse treatment of the RNA to avoid contamination with genomic DNA. 
Dilute the RNA pellet directly in DNase mastermix (per sample: $16 \mu$ DEPC treated $\mathrm{H}_{2} \mathrm{O}$, $2 \mu \mathrm{l}$ DNaase buffer, $2 \mu \mathrm{l}$ DNAse) in order to use all RNA in the following RT reaction and proceed after the manufacturer's instruction (Roche).

D. Reverse transcription of the RNA into cDNA

27. BioScript ${ }^{\mathrm{TM}}$ (Bioline) kit works well but other reverse transcriptase kits may also be used. $9 \mu \mathrm{l}$ of the DNAse treated RNA was used in a reverse transcriptase-containing and a reverse transcriptase-minus (negative control) reaction for each sample. cDNA was primed with random hexamer primers and the reaction performed according to the manufacturer's instructions.

28. Dilute the cDNA 1:4 and continue with quantitative real-time PCR analysis of target gene to identify specific changes in target mRNA level. Alternatively the cDNA can be used to generate a library.

\section{Recipes}

1. IP lysis buffer $50 \mathrm{mM}$ Hepes $(\mathrm{pH} 7.5)$

$0.4 \mathrm{M} \mathrm{NaCl}$

1 mM EDTA

$1 \mathrm{mM}$ DTT

$0.5 \%$ TritonX-100

$10 \%$ Glycerol

2. RIP buffer

$50 \mathrm{mM}$ Hepes $(\mathrm{pH} 7.5)$

$0.1 \mathrm{M} \mathrm{NaCl}$

5 mM EDTA

$10 \mathrm{mM}$ DTT

$0.5 \%$ TritonX-100

$10 \%$ Glycerol

$1 \%$ SDS

All solutions should be prepared RNAse free with Diethylpyrocarbonate (DEPC)-treated water and autoclaved before use.

\section{Acknowledgments}

This protocol was previously used in Knuckles et al. (2012). 


\section{References}

1. Knuckles, P., M. A. Vogt, S. Lugert, M. Milo, M. M. Chong, G. M. Hautbergue, S. A. Wilson, D. R. Littman and V. Taylor (2012). Drosha regulates neurogenesis by controlling neurogenin 2 expression independent of microRNAs. Nat Neurosci 15(7): 962-969. 